\title{
Ethanol Promotes Clathrin Adaptor-Mediated Endocytosis via the Intracellular Domain of $\delta$-Containing $\mathrm{GABA}_{\mathrm{A}}$ Receptors
}

\author{
Claudia Gonzalez, ${ }^{1}$ Stephen J. Moss, ${ }^{2,3}$ and Richard W. Olsen ${ }^{1}$ \\ ${ }^{1}$ Department of Molecular and Medical Pharmacology, Geffen School of Medicine, University of California, Los Angeles, Los Angeles, California 90095- \\ 1735, ${ }^{2}$ Department of Neuroscience, Tufts University School of Medicine, Boston, Massachusetts 02111, and ${ }^{3}$ Department of Neuroscience, Physiology and \\ Pharmacology, University College London, London WC1E 6BT, United Kingdom
}

Pharmacological and genetic evidence reveals that $\mathrm{GABA}_{\mathrm{A}}$ receptor $\left(\mathrm{GABA}_{\mathrm{A}}-\mathrm{R}\right)$ expression and localization are modulated in response to acute and chronic ethanol (EtOH) exposure. To determine molecular mechanisms of $\mathrm{GABA}_{\mathrm{A}}-\mathrm{R}$ plasticity in response to in vivo acute EtOH, we measured early time changes in $\mathrm{GABA}_{\mathrm{A}}-\mathrm{R}$ subunit localization. Single doses of EtOH ( $3 \mathrm{~g} / \mathrm{kg}$ via i.p. injection in rats) produced decreases in surface levels of $\mathrm{GABA}_{\mathrm{A}}-\mathrm{R} \alpha 4$ and $\delta$ subunits at 5-15 min post-EtOH in hippocampus CA1 and dentate gyrus, verifying our earlier report (Liang et al., 2007). Here we also examined the $\beta 3$ subunit and its phosphorylation state during internalization. $\beta 3$ also was internalized during $5-15$ min after EtOH exposure, while phosphorylation of $\beta 3$ was increased, then decreased at later times, ruling out $\beta 3$ dephosphorylation-dependent endocytosis. As early as $5 \mathrm{~min}$ post-EtOH, there is an initial increase in association between the $\delta$ subunits with clathrin adaptor proteins AP2- $\mu 2$ revealed by coimmunoprecipitation, followed by a decrease in association $15 \mathrm{~min}$ post-EtOH. In vitro studies using glutathione $S$-transferase fused to the $\delta$ subunit intracellular domain (ICD) show that two regions, one containing a classical Yxx $\Phi$ motif and the other an atypical R/K-rich motif, directly and differentially bind to AP2- $\mu 2$, with the former YRSV exhibiting higher affinity. Mutating both regions in the $\delta$-ICD abolishes $\mu 2$ binding, providing a possible mechanism that can explain the rapid downregulation of extrasynaptic $\alpha 4 \beta \delta$-GABA $\mathrm{A}_{\mathrm{A}}-\mathrm{R}$ following in vivo EtOH administration, in which the $\delta$-ICD increases in affinity for clathrin AP2- $\mu 2$ leading to endocytosis.

\section{Introduction}

Ionotropic $\mathrm{GABA}_{\mathrm{A}}$ receptors $\left(\mathrm{GABA}_{\mathrm{A}}-\mathrm{Rs}\right)$ mediate the majority of phasic and tonic neural inhibition in the brain and are critical for the regulation of neural activity. $\mathrm{GABA}_{\mathrm{A}}$-Rs are members of the Cysloop, heteropentameric ligand-gated ion channel superfamily. A large variety of functional $\mathrm{GABA}_{\mathrm{A}}-\mathrm{R}$ isoforms are assembled from 19 related subunits, usually in a combination of two $\alpha$ subunits $(\alpha 1-6)$, two $\beta$ subunits $(\beta 1-3)$, and one $\gamma(1-3), \delta, \varepsilon, \pi, \theta$, or $\rho(1-3)$ subunit. These individual subunits exhibit distinct, yet overlapping, expression patterns, as well as functional and pharmacological properties. Each subunit contains a large extracellular N-terminal ligandbinding domain, four membrane-spanning domains (M1-M4), a large intracellular domain (ICD), and a short extracellular C terminus (Olsen and Sieghart, 2008).

Studies show the ICD of $\beta(1-3)$ and $\gamma 2 \mathrm{GABA}_{\mathrm{A}}-\mathrm{R}$ subunits interact with various scaffolding and signaling proteins, thereby regu-

Received May 25, 2012; revised 0ct. 8, 2012; accepted 0ct. 16, 2012.

Author contributions: C.G., S.J.M., and R.W.O. designed research; C.G. performed research; S.J.M. contributed unpublished reagents/analytic tools; C.G., S.J.M., and R.W.O. analyzed data; C.G. and R.W.O. wrote the paper.

This work was supported by National Institutes of Health Grants NS35985 and AA07680, and by funds from the Department of Molecular and Medical Pharmacology, Geffen School of Medicine, UCLA, Michael Phelps, Chair. We thank Jing Liang, Kerstin Lindemeyer, and Igor Spigelman for helpful discussions.

Correspondence should be addressed to Richard W. Olsen, Department of Molecular and Medical Pharmacology, David Geffen School of Medicine at UCLA, Room CHS 23-120, 650 Young Drive South, Los Angeles, CA 90095-1735. E-mail: rolsen@mednet.ucla.edu.

DOI:10.1523/JNEUROSCI.2535-12.2012

Copyright $\odot 2012$ the authors $\quad 0270-6474 / 12 / 3217874-08 \$ 15.00 / 0$ lating the trafficking and plasticity of $\mathrm{GABA}_{A}-\mathrm{R}$ (for review, see Chen and Olsen, 2007; Jacob et al., 2008; Luscher et al., 2011). Less is known about the scarcer $\delta$ subunit and its ICD, but trafficking of $\delta$ subunits may be distinct from the mechanisms that govern trafficking of other subunits (Joshi and Kapur, 2009). The $\delta$ subunit exhibits unique properties: $\delta$-GABA $\mathrm{A}_{\mathrm{A}}$-Rs are located exclusively extrasynaptically where they tend to assemble with $\alpha 4, \alpha 6$, and $\alpha 1$ subunits only (Nusser et al., 1998; Wei et al., 2003; Liang et al., 2006; Glykys et al., 2007). With these $\alpha$ subunits, $\delta$-GABA - Rs mediate tonic currents $\left(I_{\text {tonic }}\right)$ that are sensitive to activation by the low concentrations of GABA found at extrasynaptic membrane compartments (Mody and Pearce, 2004; Meera et al., 2011), and to modulation by low concentrations of neurosteroids, some anesthetics, and EtOH (Mihalek et al., 1999; Sundstrom-Poromaa et al., 2002; Stell et al., 2003; Wallner et al., 2003; Belelli et al., 2009).

A single intoxicating dose of EtOH produced a rapid decrease in function and surface levels of $\alpha 4 / \delta$-containing $\mathrm{GABA}_{\mathrm{A}}-\mathrm{R}$ in rat hippocampus, and a slightly later upregulation of $\alpha 4 / \gamma 2$ containing $\mathrm{GABA}_{\mathrm{A}}-\mathrm{R}$, both in vivo (Liang et al., 2007; Olsen and Spigelman, 2012), and in cultured hippocampal neurons (Shen et al., 2011); the receptor subunit decrease was demonstrated as increased endocytosis rather than decreased surface insertion. These acute EtOH-induced $\mathrm{GABA}_{\mathrm{A}}$ - $\mathrm{R}$ changes were reversible in naive rats, but virtually irreversible in chronic intermittent ethanol (CIE) rats (Cagetti et al., 2003; Liang et al., 2006). Plasticity of $\mathrm{GABA}_{\mathrm{A}}$-Rs may involve regulated trafficking via protein-protein interactions. Direct interactions between membrane receptors 
and the clathrin adaptor complex (AP2), which drives clathrin coat formation and mediates endocytosis, often alter surface amounts in $\beta$ and $\gamma 2$ subunit-containing $\mathrm{GABA}_{\mathrm{A}}-\mathrm{R}$ (Kittler et al., 2000, 2005; Herring et al., 2003; Smith et al., 2008). The present study begins to identify previously uncharacterized $\delta$ interactions and their contribution to the mechanism(s) involved in the early decrease of $\mathrm{GABA}_{\mathrm{A}}-\mathrm{R}$ following EtOH exposure (Liang et al., 2007; Shen et al., 2011). How EtOH regulates restructuring of extrasynaptic $\mathrm{GABA}_{\mathrm{A}}-\mathrm{R}$ remains to be fully resolved, but the mechanisms are probably crucial to alcohol dependence and potential new approaches to treat alcohol use disorders.

\section{Materials and Methods}

Animals and EtOH treatment. The Institutional Animal Care and Use Committee approved all animal experiments. Male Sprague Dawley rats (200-350 g) were housed in the vivarium under a $12 \mathrm{~h}$ light/dark cycle and had ad libitum access to food and water. Rats were administered a single dose of $\mathrm{EtOH}(3 \mathrm{~g} / \mathrm{kg}$, as a $25 \% \mathrm{w} / \mathrm{v}$ solution in distilled water) or distilled water (vehicle) via intraperitoneal injection and decapitated 5 , $10,15,30$, or 60 min later.

Microdissection of rat brain. Following decapitation, rat brains were bathed with ice-cold artificial CSF (ACSF), removed, and quickly sliced with a tissue chopper to obtain $500 \mu \mathrm{m}$ coronal slices. Slices containing hippocampus regions were immediately placed into ice-cold ACSF, and hippocampus was microdissected for dentate gyrus (DG) and CA1 regions for normal and cross-linked Western blotting analyses (Liang et al., 2007). All slices for biochemical experiments using rat brain regions were allowed to recover in fresh ACSF at $35^{\circ} \mathrm{C}$ for $20-60 \mathrm{~min}$.

For coimmunoprecipitation analyses, only dissection of DG region was performed since DG and CA1 showed similar patterns following crosslinking experiments, and DG is richer in $\alpha 4$ and $\delta$ subunits, and can be obtained much faster and cleaner if it is the only region collected. The DG was allowed to recover in fresh ACSF, $35^{\circ} \mathrm{C}$ for $20 \mathrm{~min}$, and prepared for coimmunoprecipitation experiments. Membranes were prepared for total $\mathrm{GABA}_{\mathrm{A}}-\mathrm{R}$ subunit level analyses as discussed previously (Cagetti et al., 2003). $\mathrm{GABA}_{\mathrm{A}}-\mathrm{R} \beta 3$ subunit phosphorylation was estimated with substratespecific antibody anti-phospho- $\beta 3$ (Terunuma et al., 2008).

Cross-linking to measure surface $G A B A_{A}-R$ subunits. Following the recovery period, brain regions were incubated with or without bis(sulfosuccinimidyl)suberate (BS3) in ice-cold ACSF (Grosshans et al., 2002). Slices were homogenized in 1:4 buffer A/B; where A is 1\% SDS, $1 \mathrm{~mm}$ EDTA, 50 mм NaF, 10 mm Tris-HCl, pH 8.0, 100 mm phenylmethylsulfonyl fluoride (PMSF), and Complete Protease Inhibitor Cocktail tablet (Roche), and B is $20 \mathrm{~mm}$ Tris- $\mathrm{HCl}, \mathrm{pH} 8.0,150 \mathrm{~mm} \mathrm{NaCl}, 5 \mathrm{~mm}$ EDTA, 1\% Triton X-100, 100 mM PMSF. Protein concentration was determined by BCA Protein Assay Kit, and samples were prepared as standard for SDS-PAGE/Western blot. Relative signal intensities from each band (absorbance) were measured using ImageJ software. Samples were analyzed relative to one another on the same membrane and within the same experiment. Group differences were evaluated by two-way ANOVA, followed by post hoc Holm-Sidak test.

Membrane preparation for coimmunoprecipitation. Following the slice recovery period, brain regions were homogenized in ice-cold, freshly prepared lysis buffer (50 mm Tris, pH 8.0, 0.5 mm EDTA, 2 mm EGTA, $1 \%$ Triton X, $50 \mathrm{~mm} \mathrm{NaF}, 100 \mathrm{~mm}$ PMSF) and centrifuged at 15,000 $\times g$ for $30 \mathrm{~min}$ at $4^{\circ} \mathrm{C}$. Cell lysate was diluted to $\sim 1 \mathrm{mg} / \mathrm{ml}$ total protein, precleared with $50 \mu \mathrm{l}$ of Sepharose A beads at $4^{\circ} \mathrm{C}$ for $30-60 \mathrm{~min}$, and immediately used for coimmunoprecipitation (co-IP).

Coimmunoprecipitation. Sepharose A beads $(30-50 \mu \mathrm{l})$ were incubated with 3-10 $\mu \mathrm{g}$ of antibody for $1 \mathrm{~h}, 4^{\circ} \mathrm{C}$ before incubating with $400 \mu \mathrm{l}$ of precleared lysate, at $4^{\circ} \mathrm{C}$ for $4-18 \mathrm{~h}$. IP complexes were washed with lysis buffer, twice with TBS containing $100 \mathrm{~mm} \mathrm{NaCl}$, and once more with lysis buffer. The washed complex was eluted with $2 \times$ SDS sample buffer and boiled, and loaded on a 4-15\% gradient SDS polyacrylamide gel for protein separation, followed by transfer and antibody blotting. The secondary antibody was replaced with Clean-Blot IP HRP detection reagent (Thermo Fisher Scientific) when blotting with a same-species primary antibody as the antibody used for immunoprecipitation. Rabbit IgG (3-10 $\mu \mathrm{g})$ was used as control.

Antibodies. Dr. W. Sieghart (Medical University, Vienna, Austria) generously provided the following polyclonal $\mathrm{GABA}_{\mathrm{A}}-\mathrm{R}$ antibodies: anti- $\alpha 4$ subunit (1-14) N-terminal antibody, anti- $\alpha 4$ subunit (379-421), anti- $\beta 3$ subunit (345-408), anti-GABA $\mathrm{A}_{\mathrm{A}} \mathrm{R} \gamma 2$ subunit (319-366), anti$\mathrm{GABA}_{\mathrm{A}}-\mathrm{R} \delta$ subunit $(\mathrm{N} 1-44)$, and anti-GABA $\mathrm{A}-\mathrm{R} \delta$ subunit $(1-44)$. The anti-GABA $A_{A}-\mathrm{R}$ phospho- $\beta 3$ subunit (p408/p409) was prepared by the Moss laboratory (Terunuma et al., 2008). The following commercial antibodies were used for this study: polyclonal anti-GABA $-\mathrm{R} \delta$ subunit (331-430) from Santa Cruz Biotechnology, Inc, monoclonal mouse anti-GABA $A_{A}-\mathrm{R} \beta 2 / 3$ (clone 62-3G1) from Millipore, monoclonal mouse anti- $\beta$-actin (clone AC-15) from Sigma, polyclonal anti- $\beta$-actin from Anaspec, and monoclonal mouse anti-AP2 $\mu 2$ subunit $(110-230)$ from BD Biosciences.

Glutathione S-transferase- $\delta$ ICD $c D N A$. Glutathione $S$-transferase- $\delta$ $(\mathrm{GST}-\delta)$ cDNA containing the entire $\mathrm{GABA}_{\mathrm{A}}-\mathrm{R} \delta$ subunit ICD was discussed previously (Kittler et al., 2005). Truncated and mutated forms of GST- $\delta$ were made by standard PCR using Platinum Taq Polymerase High Fidelity (Invitrogen) with a $50 \mu$ l total reaction volume in a standard PCR cycler and the following primers, as necessary: attatcttGGATCCCACTTCAATGCCGACTACAGGAAG and attatcttGAATTCctaAGCCAACTCCTGACTGACCCC to create $\delta$ ICD residues 316-359 (called $\delta$ 316-359, or $\delta \mathrm{R}$ interchangeably); attatcttGGATCCATCTCCCGTCGTCAAGGCC attatcttGAATTCctaGATGTCGATGGTGTCTGCATCGA to create $\delta$ ICD residues 360-410 (called $\delta 360-410$, or $\delta$ Y interchangeably); attatcttGAACCTCATGGGTTCCGCTAGGTCTGTG along with primers 1 and 4 from above to create $\delta$ ICD $\left({ }^{375} \mathrm{Y} \rightarrow \mathrm{A}\right)$ mutant (also called $\delta \mathrm{Y} \rightarrow \mathrm{A}$ interchangeably); attatcttGCCGACTACGGGGCGGCAGGGGCAGCCAAGGTC was used along with primers 1 and 4 to create $\delta$ ICD $\left({ }^{322} \mathrm{RKKRK}^{326} \rightarrow\right.$ GAAGA) (also called $\delta \mathrm{R} \rightarrow \mathrm{G}$ interchangeably). The cDNA of the ${ }^{375} \mathrm{Y} \rightarrow \mathrm{A}$ mutant $(\mathrm{Y} \rightarrow \mathrm{A}$ mutant) was used as template along with mutation primer ${ }^{322} \mathrm{RKKRK}^{326} \rightarrow$ GAAGA) to create the $\delta$ ICD double $\mu 2$-motif mutant, also called $\delta 2$ mutant. Sequencing of transformed plasmid DNA verified desired constructs to use for expression of proteins.

Expression of GST fusion proteins. GST construct DNAs were transformed into Escherichia coli strain BL21, and a standard protocol for expressing and purifying GST proteins was followed (Einarson et al., 2007). Protein concentrations were determined by BCA assay. GST pulldown assays were performed as described by Kittler et al. (2005).

Concentration-dependent binding of GST-constructs to $\mu 2$. GST-affinity beads bound to GST-fusion proteins (as in pull-down experiments) were incubated with the varying concentrations of purified AP2 ( [ $1 \mathrm{nM}, 0.1$ $\mu \mathrm{M}, 0.1 \mathrm{~mm}]$ plus lysate), at $4^{\circ} \mathrm{C}$ for $2-18 \mathrm{~h}$, washed, and subjected to SDS-PAGE followed by Western blot or Coomassie stain. GST fusion mutants' binding to $\mu 2$ was normalized to its respective GST amount, and then compared with GST- $\delta$ full-length ICD (wild type). Each fulllength mutant GST was then compared with each of the others.

Statistical analysis. Normalized optical density measurements were used to calculate percentage changes, normalized according to experiment: For total protein level and surface level analysis, optical density of each band was normalized to its corresponding $\beta$-actin loading control. For coimmunoprecipitation analysis, optical density of each coimmunoprecipitated band was normalized to the original immunoprecipitated protein (the one pulled down by its specific antibody). All quantifications are expressed as the mean \pm SEM. Using the GraphPad Prism 4.0 program and SigmaStat, statistical analysis are as follows.

For Figures 1 and 2, a two-way ANOVA followed by Holm-Sidak post hoc test was used to determine significant differences among treatment time and among brain regions and between control and treated samples at a given time and region.

For each experiment in Figure 3, a two-way ANOVA followed by Bonferroni post hoc test was used to determine significant differences among treatment time and subunits.

For Figure 4C, a one-way ANOVA followed by Bonferroni post hoc test was used to determine significant differences among the constructs and binding efficacy. $p<0.001$ was considered significant that the $2 \mathrm{x}$ mutant differed in $\mu 2$ binding versus full-length wild-type $\delta$ - $\mu 2$ binding. $p<0.05$ was considered significant for the double mutant ( $2 \mathrm{X}$ mutant) binding to $\mu 2$ 

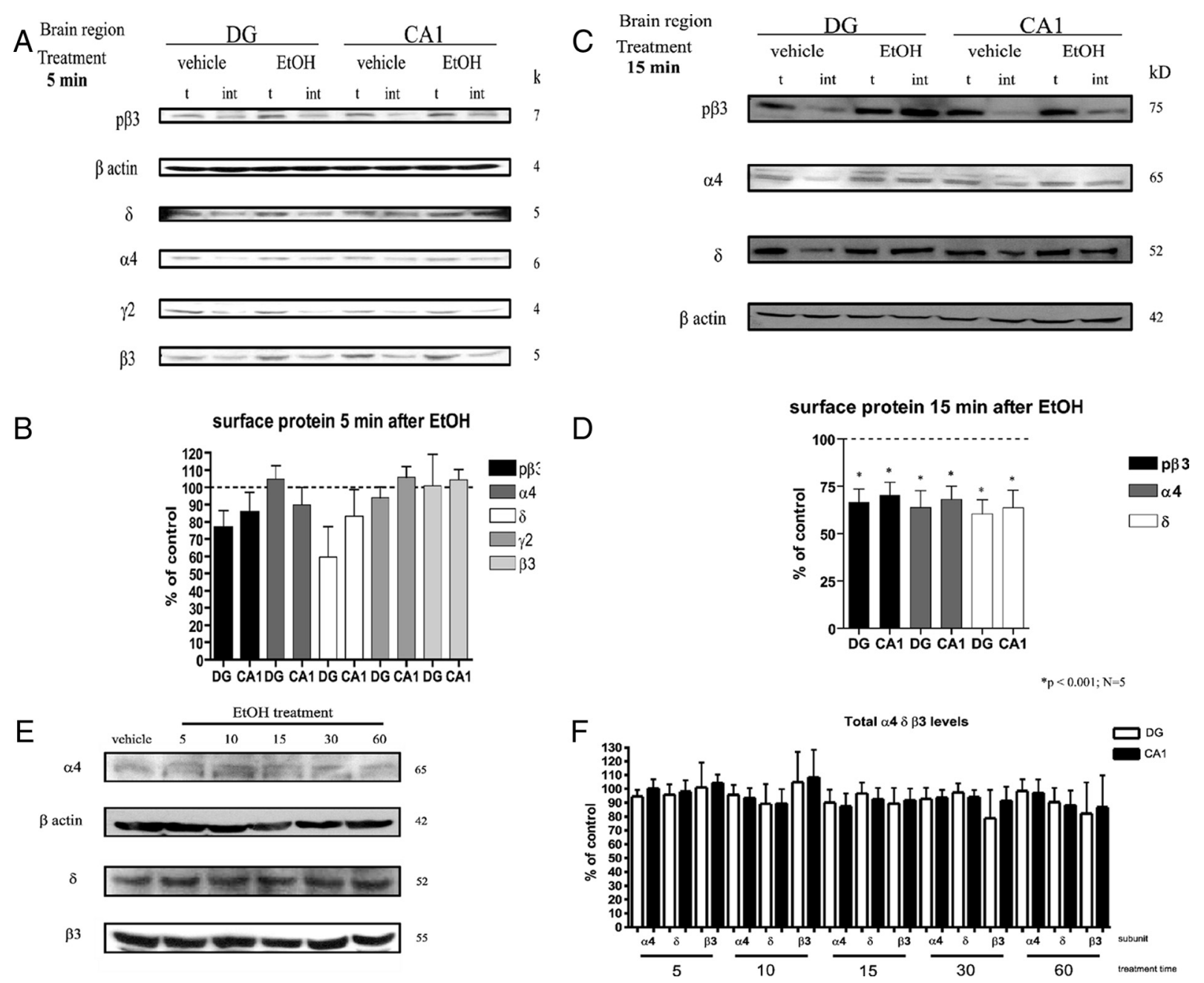

Figure 1. A single in vivo EtOH dose causes decreases in extrasynaptic surface $G A B A_{A}-R$ in hippocampal $D G$ and $C A 1$ within 15 min. $A-D$, Crosslinking experiments show a trending decrease in surface levels of $\alpha 4, \mathrm{p} \beta 3$, and $\delta$ subunits as early as $5 \mathrm{~min}$ following EtOH dose $(\boldsymbol{A}, \boldsymbol{B})$, with significant decreases measured 15 min post-EtOH $(\boldsymbol{C}, \boldsymbol{D})$. t, Total protein (untreated slices); int, internal protein (slices treated with $B S 3)$. $\beta 3$ and $\gamma 2$ showed no significant changes. Pictures show representative blots of the average changes; graphs $(\boldsymbol{B}, \boldsymbol{D})$ plot the average of several experiments, $N=5 . \boldsymbol{E}, \boldsymbol{F}, \mathrm{GABA} \mathrm{A}_{\mathrm{A}}-\mathrm{R}$ subunit levels at early time points after $\mathrm{EtOH}$ treatment. Total $\mathrm{GABA}_{\mathrm{A}}-\mathrm{R}$ subunit changes in $\mathrm{DG}$ and $\mathrm{CA1}$ at times $5-60$ min following EtOH (3 g/kg) treatment do not change significantly $(N=4-5)$.

across all other GST- $\delta$ constructs. For Figure $4 D$, a one-way ANOVA followed by a Holm-Sidak post hoc test found a significant difference between the $\delta \mathrm{Y}$ and $\delta$ Rs ability to bind to $\mu 2$ (using means as comparisons), with $p<0.05 ; N=3$ (experiment done on three batches of proteins, repeated at least twice per experiment).

\section{Results}

EtOH administration to rats induces rapid internalization of extrasynaptic hippocampal $\mathrm{GABA}_{\mathrm{A}}-\mathrm{R}$ subunits $\mathrm{EtOH}$ administered via intraperitoneal injection in rats is detectable in the brain within 2-3 min (Liang et al., 2007), and tolerance/desensitization to some EtOHinduced behavioral effects, such as rotarod performance, occurs within 3-5 min in mice (LeBlanc et al., 1975). This suggests that alterations in the function and/or expression of some $\mathrm{GABA}_{\mathrm{A}}$-Rs occur immediately after EtOH exposure. Figure $1 A-D$ shows receptor cross-linking assays using hippocampal slices in vitro, after $\mathrm{EtOH}$ administration in vivo. Rats were
A

B p $\quad p 3$ changes

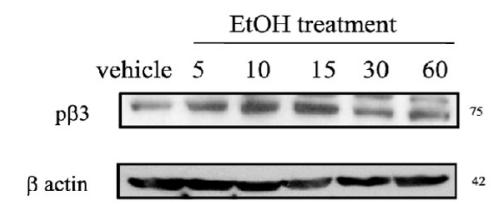

Figure 2. EtOH-induced changes in $\mathrm{GABA}_{A}-\mathrm{R} \beta 3$ phosphorylation at early time points. $A$, Phosphorylation of $\beta 3$ as identified with sequence-specific phospho-peptide antibody. Initial increases at 5 and $10 \mathrm{~min}$ in phosphorylation of $\beta 3$ subunit compared with control treated at 5 and $10 \mathrm{~min}(153.10 \pm 40.14 \%, 138.08 \pm 29.20 \%$, respectively; $N=4-5)$. $\boldsymbol{B}$, Plot of quantified $\beta 3$ level changes following various EtOH time treatments and brain regions. ${ }^{*} p<0.05$; ${ }^{* *} p<0.001$ between 5 min treatment and stated treatment times in each brain region; ${ }^{* * *} p<0.05$ between control and EtOH-treated rats from same time point treatment; two-way ANOVA.

treated with $3 \mathrm{~g} / \mathrm{kg} \mathrm{EtOH}$ (intraperitoneally), or vehicle, and killed at early time points $(5-60 \mathrm{~min})$ to determine the time course for the EtOH-induced $\mathrm{GABA}_{\mathrm{A}}-\mathrm{R}$ internalization of surface receptors, as seen in Liang et al., 2007. We simultaneously examined the phosphorylation state of the $\beta 3$ subunit over the 
A

IP $\delta \quad 5,15 \mathrm{~min}$ post EtOH:

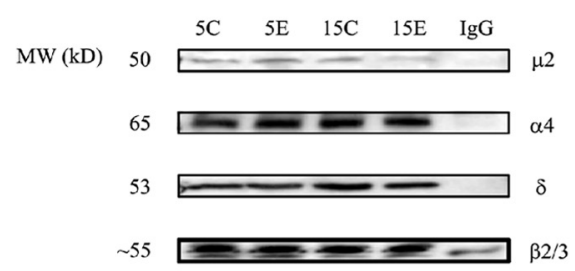

B

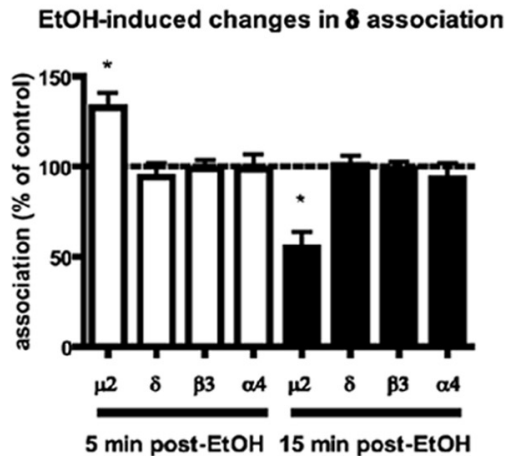

C

IP $\alpha \mathbf{4} 5,15$ min post EtOH

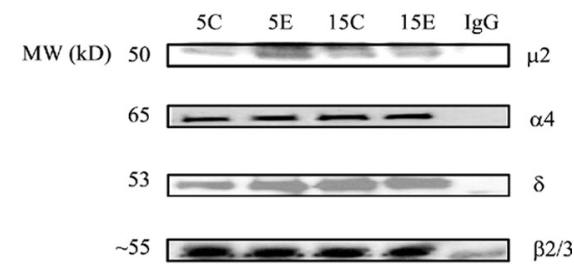

$\mathrm{D}$ EtOH induced changes in $\alpha 4$ association

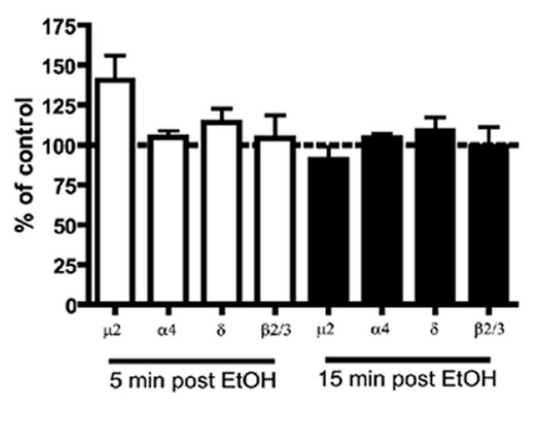

Figure 3. $\mathrm{GABA}_{A}-\mathrm{R} \delta$ and $\alpha 4$ subunit association with $\mu 2$ changes following EtOH exposures. $\boldsymbol{A}, \boldsymbol{B}$, EtOH caused a $32.7 \%$ increase in $\delta$ association with $\mu 2$ at $5 \mathrm{~min}$, and a $55.1 \%$ decrease in $\delta$ association with $\mu 215 \mathrm{~min}$ following EtOH treatment. The EtOH-induced changes in association of $\delta$ with $\mu 2$ are statistically significant from each other ( ${ }^{* *} p<0.0001$ ), and statistically significant from control treated $\delta$ - $\mu 2$ associations (two-way ANOVA, Bonferroni post hoc test; ${ }^{*} p<0.05 ; N=5$ ). $C, D, G A B A_{A}-R$ $\alpha 4$ subunit associations following EtOH exposure. Et $0 \mathrm{H}$ caused a $38 \%$ increase in $\alpha 4$ association with $\mu 2$ at $5 \mathrm{~min}$ (not significant, $p=0.05, N=4$; but was significantly different from association of $\alpha 4$ and $\mu 2$ at $15 \mathrm{~min}, p<0.001)$. This suggests that, at least at an early time point, these subunits are internalizing with $\delta$-containing $G A B A_{A}-R$.

same time course, because dephosphorylation of $\beta 3$ subunits has been shown to regulate clathrin-mediated internalization of receptors (Kittler et al., 2005; Jacob et al., 2008; Terunuma et al., 2008). Here, surface levels in $\alpha 4, \delta$, and the phosphorylated form of $\beta 3 \mathrm{GABA}_{\mathrm{A}}-\mathrm{R}$ subunits trended to a decrease as early as $5 \mathrm{~min}$ after EtOH exposure, although none was significantly different (Fig. $1 A, B)$. Statistically significant changes were seen $15 \mathrm{~min}$ after the EtOH dose, at which time surface $\alpha 4$ levels decreased to $63.9 \pm 8.8 \%$ in the DG and $68.1 \pm 6.9 \%$ in CA1; $\mathrm{p} \beta 3$ decreased to $66.8 \pm 6.5 \%$ and $70.5 \pm 6.7 \%$; and $\delta$ decreased to $60.4 \pm 7.4 \%$ and $63.8 \pm 9.2 \%$ compared with vehicle-treated rats (Fig. $1 C, D, p<0.001$, compared with control of same subunit; $N=5$ ). These results suggest that $\mathrm{EtOH}$ stimulates the internalization of receptors composed of $\alpha 4 \beta 3 \delta$ subunits. Figure $1, E$ and $F$, shows there were no changes in total $\mathrm{GABA}_{\mathrm{A}}-\mathrm{R}$ subunits tested at early time points $5-60 \mathrm{~min}$, as expected (there is no detectable degradation nor synthesis at early time points).

Dephosphorylation of $\beta 3$ subunit does not correlate in time with EtOH-induced internalization

The phosphorylated state of $\mathrm{GABA}_{\mathrm{A}}-\mathrm{R} \beta 3$ subunit was detected by Western blot with a substrate-specific antibody in control animals untreated with $\mathrm{EtOH}$. Significant increases were observed for phosphorylated $\beta 3(\mathrm{p} \beta 3)$ at early time points 5 and 10 min following EtOH treatment, times at which protein internalization was observed. The levels of $\mathrm{p} \beta 3$ decreased at later time points, 30 and $60 \mathrm{~min}$ after EtOH, as shown in Figure 2. Thus dephosphorylation does not appear to induce internalization of $\alpha 4, \beta 3$, and $\delta$ subunits of $\mathrm{GABA}_{\mathrm{A}}-\mathrm{R}$.

\section{EtOH treatment in rats increases association of hippocampal extrasynaptic $\mathrm{GABA}_{\mathrm{A}}-\mathrm{R}$ subunits with clathrin adaptor protein AP2 $\mu 2$ subunit observed by coimmunoprecipitation}

Since $\alpha 4, \mathrm{p} \beta 3$, and $\delta$ subunit surface levels significantly decreased at $15 \mathrm{~min}$ following EtOH administration (Fig. 1C,D), the effects that this treatment had on association with the clathrin $\mu 2$ subunit were measured. Coimmunoprecipitation experiments of $\delta$ subunits showed an initial significant increase in association with AP2- $\mu 2(132.7 \pm 8.2 \%$ of vehicle) as early as $5 \mathrm{~min}$ following $\mathrm{EtOH}$. There was a subsequent decrease in $\delta$ association with $\mu 2(55.1 \pm 8.7 \%$ of vehicle) $15 \mathrm{~min}$ after EtOH treatment (Fig. $3 A, B$ ). These results suggest that the increase in $\mathrm{GABA}_{\mathrm{A}}-\mathrm{R}$ internalization observed in Figure 1 (via cross-linking) is, in part, due to an increased association of pentameric receptors containing $\delta$ with $\mu 2$ at $5 \mathrm{~min}$ following EtOH treatment, resulting in an initiation of endocytosis of the $\delta$-containing receptor. The decreased $\delta$ - $\mu 2$ association $15 \mathrm{~min}$ after $\mathrm{EtOH}$, in return, supports the observation that a significant amount of $\delta$-containing $\mathrm{GABA}_{\mathrm{A}}-\mathrm{R}$ has already internalized-there is less $\delta$ available for interaction. Co-IP shows the $\delta$ subunit interacts with $\alpha 4-$ and $\beta 2 / \beta 3-\mathrm{GABA}_{\mathrm{A}}-\mathrm{R}$; there were no other changes seen in association between the $\delta$ subunit with other $\mathrm{GABA}_{\mathrm{A}}-\mathrm{R}$ subunits.

Because $\alpha 4$ subunits internalized at early time points after $\mathrm{EtOH}$ (Fig. 1), and since $\alpha 4$ is commonly found with $\delta$ subunits in the dentate gyrus, which shows increased co-IP with clathrin $\mu 2$, association between the extrasynaptic $\alpha 4$ subunits and $\mu 2$ was also measured. Coimmunoprecipitation of $\alpha 4$ subunit containing $\mathrm{GABA}_{\mathrm{A}}-\mathrm{R}$ showed a trend to increase in $\alpha 4$ association with $\mu 2$ (138.1 \pm $15.6 \%$ ) at 5 min following EtOH (Fig. 3C,D); no significant changes were seen at $15 \mathrm{~min}$. These results are consistent with the suggestion that, at least at early time points, the $\alpha 4$ subunits are internalizing with $\delta$-containing $\mathrm{GABA}_{\mathrm{A}}-\mathrm{R}$, through the same clathrin-mediated mechanism, likely as a complete functional heteropentameric complex along with $\beta$ subunits. The $\mathrm{p} \beta 3$ subunit did not appreciably pull-down with the $\mu 2$ subunit, as previously shown (Terunuma et al., 2008). Various $\mathrm{GABA}_{\mathrm{A}}-\mathrm{R}$ subunit ICDs interact directly with the $\mu 2$ subunit of the AP2 complex as cited before, and changes in these interactions are important in regulating the synaptic strength and plasticity of $\mathrm{GABA}_{\mathrm{A}}-\mathrm{R}$ (Kittler et al., 2005).

The ICD of the GABA $-\mathrm{R} \delta$ subunit binds to AP2 subunit $\mu 2$ demonstrated by GST-protein pull-downs

The $\delta$ ICD contains two possible $\mu 2$ binding motifs (Fig. $4 A$ ): a region at residues 322-334, similar to the atypical basic-rich residues $\mu 2$ binding motifs found in synaptotagmin1, $\mathrm{GABA}_{\mathrm{A}}-\mathrm{R} \beta(1-3), \gamma 2$, and GluR3, and a region containing a classical $\mathrm{Yxx} \varphi$ motif in residues $375-378\left({ }^{375} \mathrm{YRSV}\right)$. The fulllength $\delta$ ICD has been previously shown to bind to $\mu 2$ (Kittler et al., 2005). 
To determine which region(s) of the ICD directly bind $\mu 2$, GST protein fused to the ICD region of $\delta \mathrm{GABA}_{\mathrm{A}}-\mathrm{R}$ were made: GST- $\delta$ ICD full length $(316-410)$; two truncations of the $\delta$ ICD, each of which contains one of the putative $\mu 2$ binding domains; two GST- $\delta$ ICD fulllength constructs, each with one of the two $\mu 2$ binding domains mutated; and a GST $-\delta$ ICD full length with both $\mu 2$ binding domains mutated (Fig. $4 B$ ).

A GST pull-down assay confirmed that the GST-only (control) did not bind $\mu 2$, while the full-length $\delta$ ICD did bind $\mu 2$. Interestingly, both $\delta$ ICD truncations maintained partial ability to bind to $\mu 2$ (Fig. $4 C$ ): mutation of full-length $\delta$ ICD residue ${ }^{375} \mathrm{Y}$ to A (to abolish the tyrosine- $\mu 2$ binding motif) still bound $\mu 2$, suggesting that the binding to $\mu 2$ was maintained by the basic-rich $\mu 2$ binding motif. Similarly, mutation of a piece of the basic-rich region ${ }^{322}$ RKKRK to GAAGA also still bound $\mu 2$, meaning $\mu 2$ binding was maintained due to the tyrosine- $\mu 2$ binding motif. A GST- $\delta$ ICD containing both mutations ${ }^{375} \mathrm{Y} \rightarrow \mathrm{A}$ and ${ }^{322} \mathrm{RKKRK} \rightarrow$ GAAGA finally showed no binding to $\mu 2$. These results suggest that each $\mu 2$ binding region of the $\delta$ ICD is sufficient for binding to $\mu 2$, and at least one or the other motif is necessary for the $\delta$ ICD to interact with $\mu 2$.

Because each of the $\delta$ ICD regions on its own was sufficient to bind to $\mu 2$, we examined whether there was a detectable difference between the affinities for $\mu 2$. Pull-down assays using varying concentrations of purified $\mu 2$ were performed. Concentration-dependent binding studies showed (Fig. 4D) that the ${ }^{375} \mathrm{YRSV}$ motif is more sensitive to $\mu 2$ at a relative concentration of $\sim 0.1 \mu \mathrm{M}$, while the ${ }^{322} \mathrm{R} / \mathrm{K}$ motif is much less sensitive to the same concentration of $\mu 2$. The differences in binding are significant only at the lower $[\mu 2]$. These results suggest that the ${ }^{375}$ YRSV motif may be more important in the EtOH-induced increased $\mu 2$ binding, which then initiates endocytosis of $\delta$ subunit-containing receptors.

\section{Discussion}

This study provides additional evidence that $\mathrm{EtOH}$ administration to rats causes rapid internalization of $\alpha 4 \beta \delta \mathrm{GABA}_{\mathrm{A}}-\mathrm{R}$ following a single $\mathrm{EtOH}$ dose (Liang et al., 2007, Shen et al., 2011). Demonstration of increased association between $\alpha 4 \beta \delta$ $\mathrm{GABA}_{\mathrm{A}}-\mathrm{R}$ and the $\mu 2$ clathrin adaptor proteins mediating endocytosis sheds light on the possible mechanisms for regulating extrasynaptic $\mathrm{GABA}_{\mathrm{A}}-\mathrm{R}$, by changing interactions between $\mathrm{GABA}_{\mathrm{A}}-\mathrm{R}$ subunit $\delta$ and $\mu 2-\mathrm{AP} 2$. Characterization of the two one-way ANOVA; $N=3$ )
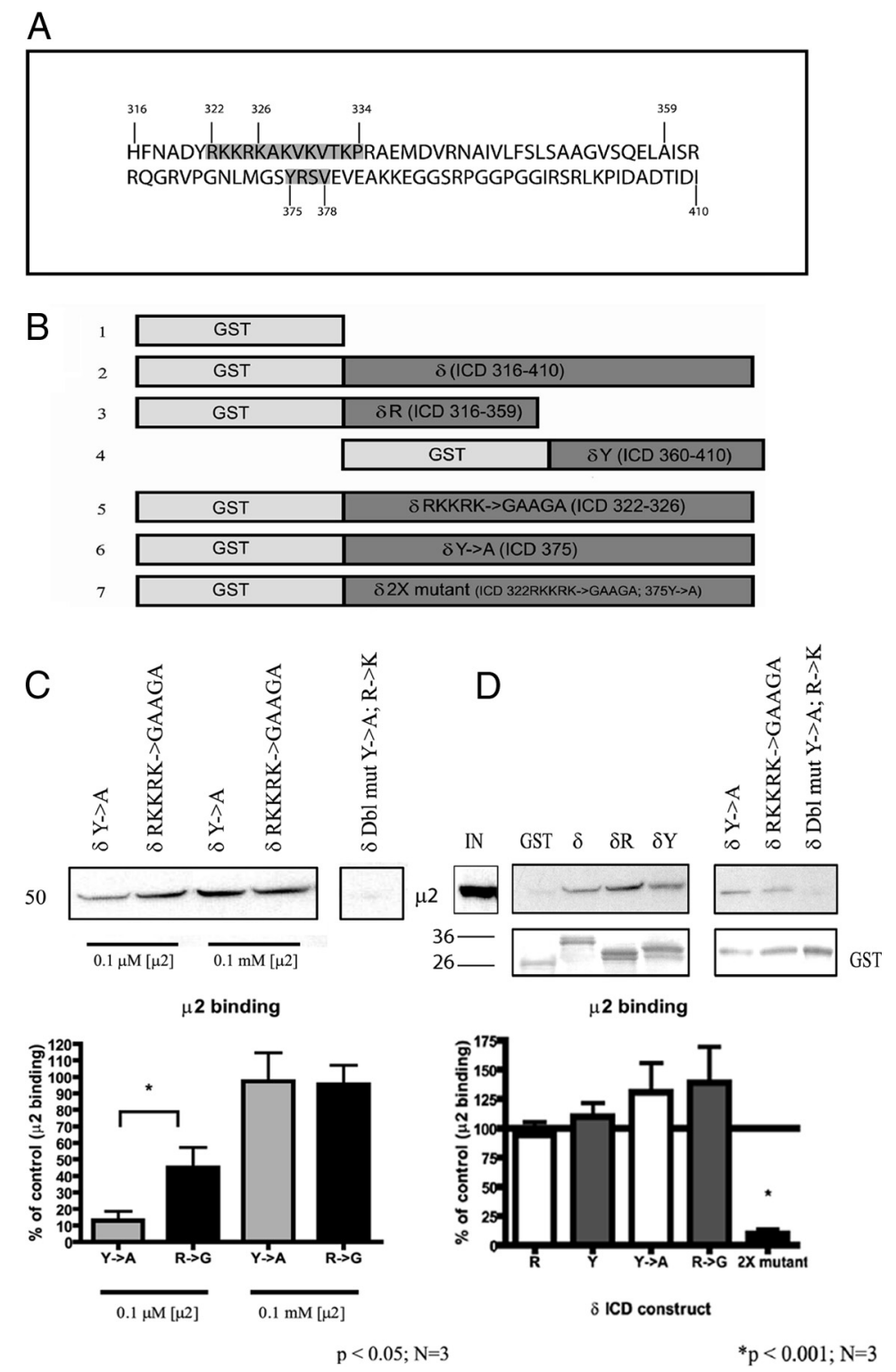

Figure 4. Characterization of $\delta$ intracellular domain. $A$, Putative $\mu 2$ binding domains within the $G A B A_{A}-R \delta$ subunit ICD. The entire rat $\delta I C D$ (aa 316 - 410) is shown. A classical Yxx $\Phi$ motif $\left({ }^{375} Y R S V\right)$ is located at residues 375-378, while an atypical basic rich motif similar to

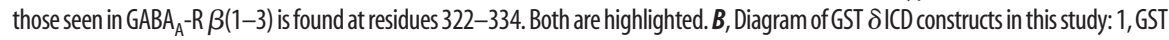
only; $2, \mathrm{GST}+\delta \mathrm{ICD}$ full-length residues $316-410(\delta) ; 3, \mathrm{GST}+$ first half of $\delta$ ICD residues $316-359(\delta R) ; 4, \mathrm{GST}+$ second half $\delta$ ICD residues $360-410(\delta Y) ; 5, G S T+\delta$ full-length $\mathrm{R} / \mathrm{K}$ piece mutated residues $322-326\left(\delta^{322}\right.$ RKKRK $\rightarrow$ GAAGA $) ; 6, \mathrm{GST}+\delta$ full-length Y375 mutated to $A\left(\delta^{375} Y \rightarrow A\right) ; 7$, GST $+\delta$ full-length, where both the ${ }^{322} \mathrm{R} / \mathrm{K}$ piece and ${ }^{375} \mathrm{Y}$ are mutated ( $\delta 2 \mathrm{X}$ mutant). C, Each $\mu 2$ binding domain of the $\delta$ ICD binds to $\mu 2$. GST-only (control) does not bind to $\mu 2$, but constructs $2-6$ all bind to $\mu 2$. This includes all $\delta$ ICD constructs containing at least one complete $\mu 2$-binding domain ( ${ }^{322} \mathrm{R} / \mathrm{K}$ region only shown as $\delta \mathrm{R}$; ${ }^{375} \mathrm{YRSV}$-only shown as $\left.\delta \mathrm{Y}\right)$. Only the construct lacking both $\mu 2$-binding domains shows no binding to $\mu 2$. Therefore, each of the two $\mu 2$ binding domains directly bind to $\mu 2$. Quantification of binding shows there are no significant differences between mutants and $\delta$ ICD full-length, except for the double mutant, which significantly lost all $\mu 2$ binding ( ${ }^{*} p<0.001$; one-way ANOVA). All other constructs are significantly different from the double mutant $\left(p<0.05\right.$; one-way ANOVA). $\boldsymbol{D}$, The ${ }^{375}$ YRSV-motif of the $\delta$ ICD detects lower [ $\left.\mu 2\right]$. The $1 \mathrm{~nm}, 0.1 \mu \mathrm{m}$, and $0.1 \mathrm{~mm}$ AP2 fractions were incubated with the GST- $\delta$ truncation proteins to see if one region binds at a lower $\mu 2$ concentration than the other. The procedure and analysis were similar to those done with the pull-down experiments, with representative blot and cumulative quantified $\mu 2$ binding plot shown here. The $1 \mathrm{~nm}$ concentration showed no binding, but $0.1 \mu$ m showed $\mu 2$ binding more to the construct lacking the basic rich region, suggesting this lower-concentration binding is more influenced by the ${ }^{375} \mathrm{YRSV}$-motif. The difference between binding seemed to be undetectable at higher $\mu 2$ concentrations, likely because the basic-rich ${ }^{322} \mathrm{R} / \mathrm{K}$ motifis now participating in its own $\mu 2$ binding $(p<0.05$;

putative $\mu 2$-binding domains within the $\delta \operatorname{ICD}$ (one $\operatorname{Yxx} \Phi$ motif and the other an $\mathrm{R} / \mathrm{K}$ rich motif) reveals that each can bind $\mu 2$ AP2 on its own. We show that the two domains exhibit differential affinity: the ${ }^{375} \mathrm{Y}$-motif is capable of binding lower 
concentrations of $\mu 2$ than the ${ }^{322} \mathrm{R} / \mathrm{K}$-rich motif of the $\delta$ subunit. Altogether, these results suggest that clathrin-mediated endocytosis directs the early EtOH-induced internalization of extrasynaptic $\mathrm{GABA}_{\mathrm{A}}-\mathrm{R}$ primarily via $\delta$ subunit interactions with $\mu 2$.

\section{EtOH-dependent downregulation of neurotransmission and tolerance resulting from ligand-induced receptor reduction}

Activity-dependent changes in neurotransmission are widespread mediators of various brain activities including learning, memory, and pathological states of neuronal excitability, often by altering the number and composition of receptors available to respond to released neurotransmitters (Collingridge et al., 2004; Arancibia-Carcamo et al., 2009). Chronic benzodiazepine exposure leads to $\mathrm{GABA}_{\mathrm{A}}$ receptor downregulation (Gallager et al., 1984; Tehrani and Barnes, 1997; Ali and Olsen, 2001; Tan et al., 2010), as does chronic EtOH treatment (Cagetti et al., 2003; Kumar et al., 2010). Such a mechanism is key to diminishing the (hyper-inhibitory) response in the face of continuous stimulus, and an initial downregulation also occurs following single doses of EtOH (Liang et al., 2007), also seen in this study. These results are consistent with a model in which agonists and positive modulators induce a conformation of the receptor that is a substrate for the biochemical events producing downregulation, possibly by cell internalization. The overstimulation of $\mathrm{EtOH}$-sensitive receptors in the presence of moderate to high doses of $\mathrm{EtOH}$ begins the first step of downregulation of the $\mathrm{EtOH}$-sensitive $\mathrm{GABA}_{\mathrm{A}}$ receptors. During the course of this study, we (Shen et al.,2011) showed that comparable 20 min effects were reproduced in primary cultured neurons as well, and also provided evidence with cleavable biotinylation that these extrasynaptic $\delta$-GABA $A_{\mathrm{A}}$-Rs directly underwent endocytosis (rather than decreased membrane insertion). This is consistent with $\delta$ - $\mathrm{GABA}_{\mathrm{A}}$-Rs as initial responders.

The results of this study are consistent with previous studies investigating how quickly tolerance to some acute EtOH effects occur in both rats and humans. Such effects are surprisingly fast, varying from minutes to $1 \mathrm{~d}$, measured both by in vivo behavior and by in vitro recording (LeBlanc et al., 1975; Pearson et al., 1997; Ludvig et al., 2001; Liang et al., 2007). Importantly, these studies show that repetitive administration (intermittent cycles) of EtOH accelerates tolerance to EtOH. The GABAergic trafficking mechanisms behind acute tolerance may provide clues to how the highly complex chronic EtOH tolerance develops.

\section{Clathrin-mediated endocytosis and phosphoregulation}

Previous studies show that $\mathrm{GABA}_{\mathrm{A}}$-Rs undergo both constitutive and activity-dependent endocytosis primarily via clathrindependent mechanisms (Kittler et al., 2000; Herring et al., 2003; Kanematsu et al., 2006). Much research on endocytosis and $\mathrm{GABA}_{\mathrm{A}}-\mathrm{R}$ shows $\beta 3$ and $\gamma 2$ regulate clathrin-AP2 endocytosis via phosphoregulation (Kittler et al., 2005; Smith et al., 2008). Such studies involve synaptic $\mathrm{GABA}_{\mathrm{A}}-\mathrm{R}$, but neither endocytosis nor phosphoregulation of extrasynaptic $\mathrm{GABA}_{\mathrm{A}}-\mathrm{R}$ have been studied. Upon detecting internalization of phospho- $\beta 3$ in this study, we considered its possible role in regulating endocytosis. However, together with results of $\mathrm{EtOH}$ exposure in cultured hippocampal neurons (Shen et al.,2011), we find that $\mathrm{EtOH}$ exposure stimulates endocytosis of $\alpha 4 \beta 3 \delta \mathrm{GABA}_{\mathrm{A}}$ - $\mathrm{R}$ with no significant changes in $\beta 2 / 3$ association with AP2 machinery. This rules out the role of phosphoregulation increasing $\mathrm{GABA}_{\mathrm{A}}-\mathrm{R}$ activity, as seen in previous $\beta 3$ studies. Phosphorylation of $\alpha 4$ is not likely responsible for endocytosis we see here, since Abramian et al. (2010) show $\alpha 4$ phosphorylation dictates insertion into the membrane, rather than endocytosis. This leads to the final possibility: primary interactions involving the $\delta$ subunit. We find evidence for $\delta$ subunit interactions with the $\mu 2$ subunit of the AP2 complex, similar to other $\mathrm{GABA}_{\mathrm{A}}-\mathrm{R}$ subunits. The basic AP2 binding motif seen in the $\delta$ subunit is similar to those found in $\mathrm{GABA}_{\mathrm{A}}-\mathrm{R} \beta$ subunits, while the ${ }^{375}$ YRSV $\delta$ motif is a classical Y motif similar to those seen in several membrane receptors, including the $\mathrm{GABA}_{\mathrm{A}}-\mathrm{R} \gamma 2$ subunit (Kittler et al., 2005; Smith et al., 2008).

Each of the two $\mu 2$ binding domains in the $\delta$ ICD was shown to bind to $\mu 2$ in vitro, as also seen with the $\gamma 2$ subunit. Interactions between $\gamma 2-\mu 2$ and $\beta 3-\mu 2$ produced additive effects on function inferring separate binding and enhancement of $\alpha \beta 3 \gamma 2$ $\mathrm{GABA}_{\mathrm{A}}-\mathrm{R}$ endocytosis (Smith et al., 2008). Because the $\beta 3$ subunit is predominantly phosphorylated in the present study, it is not likely contributing to the $\mu 2$ interaction), so its effects would not be additive for electrophysiological studies. Instead, it is likely that the loss of interaction between $\mu 2$ and $\beta 3$ is compensated by the double $\delta$ - $\mu 2$ interaction, reinforcing the notion that dephosphorylation of phospho- $\beta 3$ is not directing the early EtOHinternalization of $\mathrm{GABA}_{\mathrm{A}}-\mathrm{R}$. Obviously competition between different regulatory mechanisms including phosphoregulation of different subunits in the pentamer could complicate matters in a cell; however, some are almost certainly able to dominate over others, and anyway, most $\beta 3$ subunits and $\delta$ subunits are not in the same pentamers. The increased clathrin interaction of $\mathrm{GABA}_{\mathrm{A}}-\mathrm{R} \delta$ subunit after $\mathrm{EtOH}$ exposure seen at $5 \mathrm{~min}$ but changing to a reduction at 15 min suggests complex kinetics for endocytosis which we suggest is consistent with the loss of substrate after the process is initiated, but might reflect other factors, including possible non-clathrin-mediated endocytosis, and/or possible heterogeneity of the $\delta$ - $\mathrm{GABA}_{\mathrm{A}}-\mathrm{R}$ protein pools. Examining the electrophysiology of $\alpha \beta \delta \mathrm{GABA}_{\mathrm{A}}-\mathrm{R}$ while blocking $\mu 2$ interactions would provide a clearer answer. Further analysis on the two motifs showed differences between their apparent affinity for $\mu 2$, with the ${ }^{375}$ YRSV motif showing greater sensitivity to $\mu 2$. It is possible that the EtOH-induced increase in endocytosis is mediated primarily by the ${ }^{375}$ YRSV motif ability to bind to $\mu 2$, or both motifs are involved, with similar or different sensitivity to EtOH-induced regulation. Phosphorylation of either or both $\mu 2$ regions in $\delta$ may help regulate the binding to $\mu 2$, with subsequent results on endocytosis. To date the ICD has not been shown to be directly phosphorylated by PKC or PKA as are other GABA $\mathrm{As}$. Several studies do, however, show that $\mathrm{EtOH}$ activates several kinases, and standard PKC isoforms $(\alpha, \beta, \gamma)$ may be activated within minutes in the nucleus accumbens and hippocampus following EtOH administration in rats (e.g., Choi et al., 2008), who suggest that $\mathrm{PKC}-\delta$ phosphorylates $\delta$-containing $\mathrm{GABA}_{\mathrm{A}}-\mathrm{R}$, since PKC- $\delta$ increases the presence of $\delta \mathrm{GABA}_{\mathrm{A}}-\mathrm{R}$-mediated tonic currents. This PKC isoform may phosphorylate the $\delta$-GABA $A_{A}-\mathrm{R}$ and regulate endocytosis, possibly by direct or indirect effects on $\mu 2$ binding, as in the case of PRIP proteins (Kanematsu et al., 2006).

\section{More functional studies needed}

$\mathrm{GABA}_{\mathrm{A}}-\mathrm{R} \delta$ subunit knock-out mice show little behavioral changes in response to $\mathrm{EtOH}$, likely due to compensation by other subunits and other neurotransmitter receptors and ion channels (Mihalek et al., 1999). We reported a decrease in $\delta$-containing $\mathrm{GABA}_{\mathrm{A}}-\mathrm{R}$ currents at $1 \mathrm{~h}$ after EtOH exposure in rats (Liang et al., 2007) and in cultured neurons (Shen et al., 2011), the rationale for this study. Detecting even earlier loss of function correlating in time with increased $\mathrm{GABA}_{\mathrm{A}}-\mathrm{R}-\mu 2$ inter- 
actions would strengthen the results of these studies. It may be possible to detect $\mathrm{EtOH}$-induced rapid decreases in tonic current, $I_{\text {tonic }}$, by altering $I_{\text {tonic. }} I_{\text {tonic }}$ in the hippocampus is mainly mediated by mutually exclusive $\alpha 5-\mathrm{GABA}_{\mathrm{A}}-\mathrm{R}$ and $\delta$-GABA $\mathrm{A}-\mathrm{R}$ (Mody and Pearce, 2004), activated by different GABA concentrations: $\delta$ by basal, low [GABA], and $\alpha 5$ by increased activity-induced increases in [GABA] (Scimemi et al., 2005; Bright et al., 2011). Since EtOH has also been shown to increase GABA release (Olsen and Spigelman, 2012), both $\delta$-GABA $-\mathrm{R}$ and $\alpha 5-\mathrm{GABA}_{\mathrm{A}}-\mathrm{R}$ may be contributing to EtOH-induced $I_{\text {tonic }}$ changes in studies such as Liang et al., 2007. As such, it is possible that at early time points (i.e., 5-15 $\mathrm{min}$ ) after $\mathrm{EtOH}$, when $\delta-\mathrm{GABA}_{\mathrm{A}}-\mathrm{R}$ (directly enhanceable by $\mathrm{EtOH}$ ) begin to internalize, $\alpha 5-\mathrm{GABA}_{\mathrm{A}}-\mathrm{R}$ are being recruited/activated by the elevated amounts of GABA. Those newly active $\alpha 5-\mathrm{GABA}_{\mathrm{A}}-\mathrm{R}$ are now contributing to $I_{\text {tonic }}$ and possibly covering the ability to detect the loss of $I_{\text {tonic }}$ that is mediated by $\delta$-GABA $A_{\mathrm{A}}-\mathrm{R}$. Therefore, electrophysiological analysis of EtOHinduced tonic currents should include a pharmacological block of $\alpha 5-\mathrm{GABA}_{\mathrm{A}}-\mathrm{R}$, to decrease the heterogeneity of the receptors contributing to $I_{\text {tonic }}$ and focus mainly on $\delta \mathrm{GABA}_{\mathrm{A}}-\mathrm{R} I_{\text {tonic }}$ changes.

It is important to test the functional significance of these $\mu 2$ binding regions within the $\delta \mathrm{ICD}$, as they are likely important in regulating the cell surface number of $\delta$-containing $\mathrm{GABA}_{\mathrm{A}}-\mathrm{R}$. $\mathrm{GABA}_{\mathrm{A}}-\mathrm{R}$ containing the $\delta$ subunit as already mentioned are unique in limited regional and subcellular localization exclusively at extrasynaptic sites, unique properties including high sensitivity to GABA and low desensitization, and a particularly important role in mediating tonic inhibition. Tonic currents are seen to be responsive to low concentrations of $\mathrm{EtOH}$, and are highly sensitive to neurosteroids; therefore endocytosis of $\delta$ - $\mathrm{GABA}_{\mathrm{A}}-\mathrm{R}$ during EtOH exposure reduces important endogenous modulation by neurosteroids, as well as basal tonic inhibition in some areas. The current results suggest that tonic inhibition is subject to use-dependent downregulation, important to many physiological conditions.

\section{References}

Abramian AM, Comenencia-Ortiz E, Vithlani M, Tretter EV, Sieghart W, Davies PA, Moss SJ (2010) Protein kinase C phosphorylation regulates membrane insertion of $\mathrm{GABA}_{\mathrm{A}}$ receptor subtypes that mediate tonic inhibition. J Biol Chem 53:41795-41805.

Ali NJ, Olsen RW (2001) Chronic benzodiazepine treatment of cells expressing recombinant $\mathrm{GABA}(\mathrm{A})$ receptors uncouples allosteric binding: studies on possible mechanisms. J Neurochem 79:1100-1108. Medline

Arancibia-Carcamo IL, Yuen EY, Muir J, Lumb MJ, Michels G, Saliba RS, Smart TG, Yan Z, Kittler JT, Moss SJ (2009) Ubiquitin-dependent lysosomal targeting of $\mathrm{GABA}_{\mathrm{A}}$ receptors regulates neuronal inhibition. Proc Natl Acad Sci U S A 41:17552-17557.

Belelli D, Harrison NL, Maguire J, Macdonald RL, Walker MC, Cope DW (2009) Extrasynaptic $\mathrm{GABA}_{\mathrm{A}}$ receptors: form, pharmacology, and function. J Neurosci 29:12757-12763. CrossRef Medline

Bright DP, Renzi M, Bartram J, McGee TP, MacKenzie G, Hosie AM, Farrant M, Brickley SG (2011) Profound desensitization by ambient GABA limits activation of $\delta$-Containing $\mathrm{GABA}_{\mathrm{A}}$ receptors during spillover. J Neurosci 31:753-763. CrossRef Medline

Cagetti E, Liang J, Spigelman I, Olsen RW (2003) Withdrawal from chronic intermittent ethanol treatment changes subunit composition, reduces synaptic function, and decreases behavioral responses to positive allosteric modulators of $\mathrm{GABA}_{\mathrm{A}}$ receptors. Mol Pharmacol 63:53-64. CrossRef Medline

Chen ZW, Olsen RW (2007) $\mathrm{GABA}_{\mathrm{A}}$ receptor associated proteins: a key factor regulating $\mathrm{GABA}_{\mathrm{A}}$ receptor function. J Neurochem 100:279-294. CrossRef Medline

Choi DS, Wei W, Deitchman JK, Kharazia VN, Lesscher HMB, McMahon T, Wang D, Qi ZH, Sieghart W, Zhang C, Shokat KM, Mody I, Messing RO (2008) Protein kinase $\mathrm{C} \delta$ regulates ethanol intoxication and enhance- ment of GABA-stimulated tonic current. J Neurosci 28:11890-11899. CrossRef Medline

Collingridge GL, Isaac JTR, Wang YT (2004) Receptor trafficking and synaptic plasticity. Nat Rev Neurosci 5:952-962. CrossRef Medline

Einarson MB, Pugacheva EN, Orlinick JR (2007) Identification of proteinprotein interactions with glutathionine-S-transferase (GST) fusion proteins. CSH protoc. Advance online publication. Retrieved November 20, 2012. doi:10.1101/pdb.top11. CrossRef

Gallager DW, Lakoski JM, Gonsalves SF, Rauch SL (1984) Chronic benzodiazepine treatment decreases postsynaptic GABA sensitivity. Nature 308: 74-77. CrossRef Medline

Glykys J, Peng Z, Chandra D, Homanics GE, Houser CR, Mody I (2007) A new naturally occurring $\mathrm{GABA}_{\mathrm{A}}$ receptor subunit partnership with high sensitivity to ethanol. Nat Neurosci 10:40-48. CrossRef Medline

Grosshans DR, Clayton DA, Coultrap SJ, Browning MD (2002) Analysis of glutamate receptor surface expression in acute hippocampal slices. Science STKE 2002 (137):p18.

Herring D, Huang R, Singh M, Robinson LC, Dillon GH, Leidenheimer NJ (2003) Constitutive $\mathrm{GABA}_{\mathrm{A}}$ receptor endocytosis is dynamin-mediated and dependent on a dileucine AP2 adaptin-binding motif within the $\beta 2$ subunit of the receptor. J Biol Chem 278:24046-24052. CrossRef Medline

Jacob TC, Moss SJ, Jurd R (2008) GABA(A) receptor trafficking and its role in the dynamic modulation of neuronal inhibition. Nat Rev Neurosci 9:331-343. CrossRef Medline

Joshi S, Kapur J (2009) Slow intracellular accumulation of $\mathrm{GABA}_{\mathrm{A}}$ receptor $\delta$ subunit is modulated by brain-derived neurotrophic factor. Neuroscience 164:507-519. CrossRef Medline

Kanematsu T, Yasunaga A, Mizoguchi Y, Kuratani A, Kittler JT, Jovanovic JN, Takenaka K, Nakayama KI, Fukami K, Takenawa T, Moss SJ, Nabekura J, Hirata M (2006) Modulation of GABA $A_{A}$ receptor phosphorylation and membrane trafficking by phospholipase C-related inactive protein/protein phosphatase 1 and $2 \mathrm{~A}$ signaling complex underlying brain-derived neurotrophic factor-dependent regulation of GABAergic inhibition. J Biol Chem 281:22180-22189. CrossRef Medline

Kittler JT, Delmas P, Jovanovic JN, Brown DA, Smart TG, Moss SJ (2000) Constitutive endocytosis of $\mathrm{GABA}_{\mathrm{A}}$ receptors by an association with the adaptin AP2 complex modulates inhibitory synaptic currents in hippocampal neurons. J Neurosci 20:7972-7977. Medline

Kittler JT, Chen G, Honing S, Bogdanov Y, McAinsh K, Arancibia-Carcamo IL, Jovanovic JN, Pangalos MN, Haucke V, Yan Z, Moss SJ (2005) Phospho-dependent binding of the clathrin AP2 adaptor complex to $\mathrm{GABA}_{\mathrm{A}}$ receptors regulates the efficacy of inhibitory synaptic transmission. Proc Natl Acad Sci U S A 102:14871-14876. CrossRef Medline

Kumar S, Suryanarayanan A, Boyd KN, Commerford CE, Lai MA, Ren Q, Morrow AL (2010) Ethanol reduces $\mathrm{GABA}_{\mathrm{A}} \alpha 1$ subunit receptor surface expression by a PKC $\gamma$ dependent mechanism in cultured cerebral cortical neurons. Mol Pharmacol 77:793-803. CrossRef Medline

LeBlanc AE, Kalant H, Gibbins RJ (1975) Acute tolerance to ethanol in the rat. Psychopharmacologia 41:43-46. CrossRef Medline

Liang J, Zhang N, Cagetti E, Houser CR, Olsen RW, Spigelman I (2006) Chronic intermittent ethanol-induced switch of ethanol actions from extrasynaptic to synaptic hippocampal $\mathrm{GABA}_{\mathrm{A}}$ receptors. J Neurosci 26: 1749-1758. CrossRef Medline

Liang J, Suryanarayanan A, Abriam A, Snyder B, Olsen RW, Spigelman I (2007) Mechanisms of reversible $\mathrm{GABA}_{\mathrm{A}}$ receptor plasticity after ethanol intoxication. J Neurosci 27:12367-12377. CrossRef Medline

Ludvig N, George MA, Tang HM, Gonzales RA, Bungay PM (2001) Evidence for the ability of hippocampal neurons to develop acute tolerance to ethanol in behaving rats. Brain Res 900:252-260. CrossRef Medline

Luscher B, Fuchs T, Kilpatrick CL (2011) $\mathrm{GABA}_{\mathrm{A}}$ receptor traffickingmediated plasticity of inhibitory synapses. Neuron 70:385-409. CrossRef Medline

Meera P, Wallner M, Otis TS (2011) Molecular basis for the high THIP/ gaboxadol sensitivity of extrasynaptic $\mathrm{GABA}_{\mathrm{A}}$ receptors. J Neurophysiol 106:2057-2064. CrossRef Medline

Mihalek RM, Banerjee PK, Korpi ER, Quinlan JJ, Firestone LL, Mi ZP, Lagenaur C, Tretter V, Sieghart W, Anagnostaras SG, Sage JR, Fanselow MS, Guidotti A, Spigelman I, Li Z, DeLorey TM, Olsen RW, Homanics GE (1999) Attenuated sensitivity to neuroactive steroids in $\mathrm{GABA}_{\mathrm{A}}$ receptor $\delta$ subunit knockout mice. Proc Natl Acad Sci U S A 96:12905-12910. CrossRef Medline

Mody I, Pearce RA (2004) Diversity of inhibitory neurotransmission 
through $\mathrm{GABA}_{\mathrm{A}}$ receptors. Trends Neurosci 27:569-575. CrossRef Medline

Nusser Z, Sieghart W, Somogyi P (1998) Segregation of different GABA receptors to synaptic and extrasynaptic membranes of cerebellar granule cells. J Neurosci 18:1693-1703. Medline

Olsen RW, Sieghart W (2008) International Union of Pharmacology. LXX. Subtypes of gamma-aminobutyric acid $_{\mathrm{A}}$ receptors: classification on the basis of subunit composition, pharmacology, and function. Update. Pharmacol Rev 60:243-260. CrossRef Medline

Olsen RW, Spigelman I (2012) GABA $_{\mathrm{A}}$ receptor plasticity in alcohol withdrawal. In: Jasper's basic mechanisms of the epilepsies, Vol 4, Chap 43 (Noebels J, Avoli M, Rogawski M, Olsen RW, Delgado-Escueta AV, eds), pp 562-573. Oxford, UK: Oxford UP.

Pearson BJ, Donatelli DP, Freund RK, Palmer MR (1997) Differential development and characterization of rapid acute neuronal tolerance to the depressant effects of ethanol on cerebellar Purkinje neurons of lowalcohol-sensitive and high-alcohol-sensitive rats. J Pharmacol Exp Ther 280:739-746. Medline

Scimemi A, Semyanov A, Sperk G, Kullmann DM, Walker MC (2005) Multiple and plastic receptors mediate tonic $\mathrm{GABA}_{\mathrm{A}}$ receptor currents in the hippocampus. J Neurosci 25:10016-10024. CrossRef Medline

Shen Y, Lindemeyer AK, Spigelman I, Sieghart W, Olsen RW, Liang J (2011) Plasticity of $\mathrm{GABA}_{\mathrm{A}}$ receptors following ethanol pre-exposure in cultured hippocampal neurons. Mol Pharmacol 79:432-442. CrossRef Medline

Smith KR, McAinsh K, Chen G, Arancibia-Carcamo IL, Haucke V, Yan Z, Moss SJ, Kittler JT (2008) Regulation of inhibitory synaptic transmission by a conserved atypical interaction of $\mathrm{GABA}_{\mathrm{A}}$ receptor [beta]- and [gamma]-subunits with the clathrin AP2 adaptor. Neuropharmacology 55:844-850. CrossRef Medline
Stell BM, Brickley SG, Tang CY, Farrant M, Mody I (2003) Neuroactive steroids reduce neuronal excitability by selectively enhancing tonic inhibition mediated by $\delta$ subunit-containing $\mathrm{GABA}_{\mathrm{A}}$ receptors. Proc Natl Acad Sci U S A 100:14439-14444. CrossRef Medline

Sundstrom-Poromaa I, Smith DH, Gong QH, Sabado TN, Li X, Light A, Wiedmann M, Williams K, Smith SS (2002) Hormonally regulated $\alpha 4 \beta 2 \delta$ GABA(A) receptors are a target for alcohol. Nat Neurosci 5:721722. Medline

Tan KR, Brown M, Labouèbe G, Yvon C, Creton C, Fritschy JM, Rudolph U, Lüscher C (2010) Neural bases for addictive properties of benzodiazepines. Nature 463:769-774. CrossRef Medline

Tehrani MH, Barnes EM Jr (1997) Sequestration of gamma-aminobutyric acidA receptors on clathrin-coated vesicles during chronic benzodiazepine administration in vivo. J Pharmacol Exp Ther 283:384-390. Medline

Terunuma M, Xu J, Vithlani M, Sieghart W, Kittler J, Pangalos M, Haydon PG, Coulter DA, Moss SJ (2008) Deficits in phosphorylation of $\mathrm{GABA}_{\mathrm{A}}$ receptors by intimately associated protein kinase $\mathrm{C}$ activity underlie compromised synaptic inhibition during status epilepticus. J Neurosci 28: 376-384. CrossRef Medline

Wallner M, Hanchar HJ, Olsen RW (2003) Ethanol enhances $\alpha 4 \beta 3 \delta$ and $\alpha 6 \beta 3 \delta \gamma$-aminobutyric acid type A receptors at low concentrations known to affect humans. Proc Natl Acad Sci U S A 100:15218-15223. CrossRef Medline

Wei W, Zhang N, Peng Z, Houser CR, Mody I (2003) Perisynaptic localization of $\delta$ subunit-containing $\mathrm{GABA}_{\mathrm{A}}$ receptors and their activation by GABA spillover in the mouse dentate gyrus. J Neurosci 23:1065010661. Medline 